\title{
Opportunities and Challenges: Chinese Newspapers in Transition*
}

\author{
HU Xiao-juan \\ Dalian University of Technology, Dalian, China
}

\begin{abstract}
Chinese newspaper industry has entered into a new historical period; the prospect of newspaper is becoming an important topic of academic and industrial. Facing the media ecological reconstruction brought by media convergence, mobile circumstance, and internet plus, the norm of newspaper media in the past has been broken, facing new adjustment. Newspaper explored with hard since it confronted both opportunities and challenges. This article summarizes the basic situation and main advantages of newspaper media development. By analyzing newspaper transformation practice, this paper tries to discuss the future direction and what newspaper media can achieve in view of the current main difficulties. The analysis of the essence and effect of newspaper transformation, as well as the rationalization proposals, will be beneficial for newspaper media to recognize the situation, find the correct position, and create expression, so as to meet both opportunities and challenges.
\end{abstract}

Keywords: newspaper transformation, media convergence, internet thinking, profit model, new media technology

\section{Basic Situation and Frame Advantage of Chinese Newspaper Media}

In recent years, newspaper recession trend deepens in the face of new media environment and communication pattern, with circulation and advertising "bluff type" sliding, suspension of publication increasing year by year. It is predicted that more than two-thirds of newspaper will be "shut down or turning" in 2018 (Ma \& Hu, 2016). There's a lot of talk about newspaper fate, such as "winter theory", "inflection point", and "the fade of newspaper".

The change of information production mode driven by new media technology has dispelled the monopoly power of information production and release. Traditional newspapers should meet the "new normal" of newspaper industry by transforming actively, inspecting old problems with new eyes. Actually, positive view is inclined to transformation of newspaper industry development, with both opportunities and challenges.

As the main representative of traditional media, the newspaper is an important part of media ecology with unique frame advantage, which is communication capability, guiding force, credibility, and influence based on the authority, ideological and profundity in content. Newspaper serves as not only information source for new media, also provides confirmation and evaluation to expand information depth and set the agenda for new media. What's more, newspaper's investigative journalism, in-depth reporting and comments, has built the remarkable influence and quality of print media platform with unique strength and ideological, which is the soul of the newspaper.

\footnotetext{
* This paper is fund by Dalian University of Technology Introduction of Talent Research Project 2 (DUT18RC (4) 003).

HU Xiao-juan, Ph.D., Lecturer, Master Supervisor, Department of Humanities and Social Sciences, Dalian University of Technology.
} 
Newspaper's frame advantage has profound influence on audience. In the media field, the development of technology and the change of media environment highlight the importance of content in the competition. In most cases, only professional journalist from newspaper can better finish some high quality reports since they have unique advantages in terms of money, organization, and logistics. American scholar Philip Meyer (2004) who has put forward "the fade of newspaper", however he also set forth newspaper's influence economy. He believed that the main product of newspaper is influence rather than news or information.

With the diversification of information access channel, releasing information is no longer media privilege. Instead, how to estimate, interpret, and verify information thereby providing authoritative interpretation and in-depth reporting becomes especially important. As a result, news competition mainly focused on the right of information interpretation rather than news sources in traditional sense.

\section{Chinese Newspaper Transformation Practice}

Chinese newspaper industry has entered into a new historical period; the prospect of newspaper is becoming an important topic of academic and industrial. Facing the impact of new media, newspaper media has been struggling to explore and innovate in transformation practice.

\section{Deep Reform of Newspaper Industry Steadily Progress}

Deep reform has provided an internal impetus for a new round of newspaper industry prosperity and a strong guarantee for the newspaper smooth development. On the one hand, newspaper industry reform follows the survival of the fittest, untenable newspaper withdraw from the market, reducing homogenous and vicious competition.

On the other hand, newspaper promotes cross-border integration and structural adjustment to enlarge scale effect, cultivating several new media group with powerful strength. Some newspapers have established special new media centers leveraging new media companies' commercial operation. Take People's Daily for example, it has far beyond the scope of a newspaper, but a collection site of microblog, wechat, app, mobile news, network television, etc., which basically covers all kinds of existing communication form (Yuan, 2014).

\section{Reinvention of New Technology for Content Production}

News content has been presented in endless ways driven by technology innovation, since text, picture, visual data, H5 news, video, even immersive reporting like VR or AR. Xinhua news agency's Data News received sought after, while Action News from Beijing News changed the style of traditional two sessions reports. In 2016, 12 newspapers in China jointly set up VR news laboratory to explore new forms of information. Particularly, China's media convergence cloud realized one-stop solution to media technology problems. Big data operation, artificial intelligence application, and new content production are no longer conundrum.

Newspapers set up omnimedia editing platforms one after another using new media technology, such as "central kitchen" of People's Daily, which breaks away from integration draft library through the whole process and constructs complete content production line, realizing content sharing of entire industry even cross-industry. Finally, it leads a batch of media to reform and innovate in the direction of "once collection, diverse generation and multiple transmission".

\section{Indefatigable Exploration of Effective Profit Model}

With the increasing dominance of mobile communication and mobile terminals, newspapers' traditional business model "content + advertising" is unsustainable. Newspaper industry needs to explore mature profit model. 
New business model based on print media is expanding. Newspaper actively participated in the construction of database engineering, and gradually found the connection point of the Internet and related industries by means of exploiting big data resource. This year, Henan Daily Newspaper Group effectively responded to newspaper profit dilemma by launching diversified operation with $65 \%$ non-newspaper revenue of finance, advertising, hotel, and education (Xie, 2018).

Also, Newspapers are innovating in release services and reading forms, exploring newspaper space of the second and third-tier cities that have not yet penetrated into new media, and exerting the potential of metropolitan newspapers. It has become a new attempt to expand stereoscopic distribution channel for some newspapers to present Pad terminal reader.

\section{Positively Meet the Media Convergence}

As early as 2014, the first year of media convergence in China, integration of traditional media and emerging media has become a national strategy (Jia, Yin, \& Deng, 2014). Newspaper media gradually embraced new media to explore new form of expression suitable for the Internet. Since media convergence accelerated, the strength and depth continuously reinforced.

Nowadays, microblog, wechat, and App have become a standard of traditional media. The official microblog of People's Daily has created fresh public opinion atmosphere different from newspaper maternal. People's Daily App downloads more than 5 million after online two months. The Paper App adapts to new spread in mobile Internet era, whose users has far more than its newspaper's readership.

\section{Predicament and Direction of Chinese Newspaper Industry}

The practice of Newspaper transformation is beset with difficulties. The fundamental difficulty with newspaper at present, for one thing is deficiency of communication ability as a platform, for another is business distress. On account of lacking of distinct business model, newspaper content becomes difficult to liquidate.

Newspaper transformation seems embarrassing since newspaper form was abandoned relentlessly and the boundary between main business and sideline production is often confused. It is difficult to define clearly whether the transition succeeds or not. As for the essence of transformation, it similarly lacks of introspection.

\section{Promoting Media Convergence With Internet Thinking}

Study of media convergence pays too much attention to technology, strategy, and effects, neglecting the contact of media convergence and media security. In fact, media mergence era brings both vigor and challenges to media safety. China's media security is still serious in the era of media convergence. Therefore, more attention needs to be paid to the information security maintenance, new media public opinion, and policy regulations.

Media convergence centers on exploring new forms of expression suitable for the Internet (Li \& Zhou, 2014). Professor Chen Lidan (2014) pointed out that "Internet thinking" needs to use communication features of the Internet to think deeply about media convergence.

Media convergence is no longer the shift between traditional media and new media, but the share of advantage resource and cooperation of reconstituted regulation under New Barrel Theory. Anyhow, the evolution of media form will not change the value of news.

Newspaper media should strive to build a series of self-controlled new media platforms and integrate superiorities. Meanwhile newspaper should provide a mingled space for traditional business and new media, ascending discourse power and influence in the field of new media public opinion. 


\section{Providing Quality and Irreplaceable Content}

Facing the change of information acquisition terminals and consumption habits, newspaper media must spare no effort to create mobile media products and update ideas and technologies. Because of media market segmentation, information resources obtained by newspaper need to be integrated and developed repeatedly, effectively transforming the long-term accumulated political and economic advantage resources.

Leveraging big data and cloud computing technology, users' needs can be precisely analyzed, which improves the pertinence of news reporting and service. Turn your audience into users and embrace collaborative innovation to bring content video presentation, precise push, and multi-channel marketing.

In the future, newspaper media needs to identify themselves and differentiate in content and communication. Besides, it must be familiar with the way news will be consumed in times to come, thus creating unique products. Newspapers have to do more different things than simply do the same things better.

\section{Exerting the Initiative and Creativity of Journalist}

As subject of communication, journalists are the key to the success of newspaper transformation. The current talent competition needs high-level management personnel, high-quality business backbone, and new media technology talents, as well as a group of editors and journalists with team awareness and loyalty.

In conclusion, newspaper media is supposed to establish modern enterprise system to attract and retain talents, making good use of talents.

However, journalist subjective initiative muse not surpass or violate news reality. The authenticity of news has always been emphasized as the life of news. The collusion of technology and capital has brought simulation and fiction, eliminating the real, which has become the great challenge of cognition and identification. As the logical basis for modern human cognitive structures, real system is facing the challenges of the new media. Nowadays, the transformation of the media technology and media competition put forward higher requirements for journalists' scientific literacy. Scientific literacy has expanded from citizen groups to other industries. Journalists should defend the real and promote literacy.

\section{Discussion}

There are other issues that deserve attention and discussion for subsequent research deepened.

\section{Rethinking Newspaper Industry in Transition}

Newspaper transformation, in terms of effect, is nothing more than the change of profit, audience, market, and influence brought by some new concepts, orientations, and practices.

In fact, newspaper transformation is more than increasing profitability or making a fresh start. The essence of media is platform, which can be directionally charged or diversified manage after the platform becomes bigger and stronger.

Therefore, newspaper industry transformation should first establish an information platform that can bring revenue. Secondly, it should be closely correlated with traditional media's core business. Most importantly is to strengthen the core feature of media and maintain the influence and communication value.

Maybe the feasible framework of future newspaper industry is mainly newspaper-oriented, leaving media as a platform for influence and public opinion. Profit platform will be transferred to other supporting industry with media as the core connection. Namely, strengthening public opinion guiding, forging media structure with profit platform supports public opinion platform. 


\section{Journalists' Professional Identity in Transition}

Future research direction about newspapers in transition cannot ignore journalists' professional identity.

With the vigorous development of China's media industry, Chinese journalists have increasingly expanded to a very large occupational group with sharp differentiation. Faced with the media environment changes, diversity of social values, as well as various pressure and temptation in news production practice, a batch of journalists who have the temperament of idealism go out of press active or passive. Since journalism ethics anomie has got worse, social evaluation has fallen, and self-identity has derogated, journalists' professional identity presents a complex and diverse picture.

Journalists' professional identity studies reference to relevant theory from journalism and communication, sociology, management, psychology, and other disciplines, such as professional role, identity, interpretive community, professional community, journalistic professionalism, compensation evaluation system etc.

We can interpret the construction logic of professional identity from three aspects: the historical tradition of scholar's political commentary and news production, the balance between self-evaluation and social evaluation, macro, meso, and micro.

Journalists' occupational identity is about how journalists' cognition of news, what news career (journalists) should be (ideal) and whether to have become such practitioners. The professional identity starts with journalists as action subjects, exploring the history, current situation and influencing factors of professional identity, so as to build a favorable concept of professional identity. Even more important, this paper gets rid of the commonly used binary analysis framework of country and market in news production process, focusing on specific group identity of journalists and the changes of their professional identity to explore the connection with the macro context in transitional China, social environment, media scene, and personal emotion.

Therefore, talent problem in newspaper transformation should answer the following questions:

(1) The history of professional identity: What are the life experience and development of journalists' professional identity?

(2) The current situation of professional identity: What is journalism?

(3) The ideal of professional identity: What journalism should be?

(4) The influencing factors of professional identity.

(5) Different latitude and level of the construction of professional identity logic.

(6) How do professional community shape and influence professional identity?

In the field of Internet, with the increase of social identities and the maintenance of social fairness and justice, the complex relations and social psychological problems brought by the group communication have increasingly challenged the professional dominance of journalists as the main body of information production.

Journalists' identity crisis is related to the future of journalism. Journalists need to re-establish professionalism, restore professional values and glory, and reshape professional ideals and identities.

Actually, journalists generally believe that professional identity problem is of great importance. The ideal of professional keeps firm whatever real dilemmas are. Journalists' professional identity is a complex about the positive cognition of internalized professional role, experience, and behavior tendency. Professional identity directly affects the bottom line, professional values and motivation. Journalists' professional identity is mainly manifested in three dimensions, professional cognition, professional evaluation, and professional emotion, which exists internal connection and influence between each other. With cognition gradually clear, evaluation 
more reasonable, emotion turning to positive, professional identity also become gradually enhanced. Influencing factors of journalists' professional identity diversify gradually, often will be affected by external environment and evaluations as well as internal cognitive and emotions, and always in constant compromise and nervous. Therefore, the formation of professional identity is the interactions between individual cognition and social refinement. Contradictions from system, function, and conception interweave in the history and reality, self and social evaluation, forming the special scene of the construction of professional identity. The construction and even reinforcement of journalists' professional identity needs professional community's support from the social structure level, at the same time, needs professional ideal's motivation from the value level.

How journalists respond to the changes of the professional identity will provide a better understanding of journalists and media circumstance, also a new perspective for understanding Chinese news reform. Furthermore, this article provides a certain reference for reinforcing newspaper transformation, promoting sustainable development and professional level of journalism, which will benefit healthy news production to accommodate the media change.

\section{References}

Aidridge, M., \& Evetts, J. (2003). Rethinking the concept of professionalism: The case of journalism at daily newspaper. British Journal of Sociology, 54(4), 547-564.

Bertrand, C. J. (2000). Media ethics and accountability systems. New Jersey: Transaction Publishers.

Brown, R. (2000). Social identity theory: Past achievements, current problems and future challenges. European Journal of Social Psychology, 30(6), 745-778.

Bruns, A. (2011). Gatekeeping, gatewatching, real-time feedback: New challenges for journalism. Brazilian Journalism Research Journal, 7(2), 117-136.

Chen, L. D. (2014). Promote media convergence with Internet thinking. Contemporary Communications, 6, 1.

Clerwall. (2014). Enter the robot journalist: Users' perceptions of automated content. Journalism Practice, 8(5), 519-531.

Coover, G. E. et al. (2000). The communicated self: Exploring the interaction between self and social context. Human Communication Research, 26(1), 125-147.

De Burgh, H. (2003). Kings without crowns? The re-emergence of investigative journalism in China. Media Culture \& Society, 25, 801-820.

Deuze, M. (2005). What is journalism?-Professional identity and ideology of journalists reconsidered. Journalism, 6(4), 442-464.

Eyal, Z. (2010). The right to tell the (right) story: Journalism, authority and memory. Media, Culture \& Society, 32(1), 5-32.

Hanitzsch, T., \& Vos, T. P. (2017). Journalistic roles and the struggle over institutional identity: The discursive constitution of journalism. Communication Theory, 27(2), 115-135.

Hassid, J. (2008). China's contentious journalists: Reconceptualizing the media. Problems of Post-Communism, 55(4), 52-61.

Hassid, J. (2011). Four models of the fourth estate: A typology of contemporary Chinese journalists. The China Quarterly, 12(208), 813-832.

Jia, Z. J., Yin, C., \& Deng, X. Q. (2014). Research on current situation and countermeasures of Chinese media convergence. Science-Technology \& Publication, 10, 137.

Latar, N. L. (2015). The robot journalist in the age of social physics: The end of human journalism? The New World of Transitioned Media: Digital Realignment and Industry Transformation, 1, 65-80.

Li, L. R., \& Zhou, K. W. (2014). Media convergence: Old routines and new exploration. Journalist, 8, 18-19.

Ma, C. J., \& Hu, P. (2016). Research on the dilemma and countermeasures of traditional newspapers in the new media environment. Today's Massmedia, 12, 84-85.

Macdonald, K. M. (1995). The sociology of the professions. London: Sage.

Meyer, P. (2004). The vanishing newspaper: Saving journalism in the information age. Columbia: University of Missouri Press.

Meyer, P. (2008). Certification of journalists: Necessary for our times. Electronic News, 2(1), 1-5. 
Qiu, J. (2016). Research and development of artificial intelligence in China. National Science Review, 3(4), 538-541.

Siebert, F. S., Peterson, T., \& Schramm, W. (1956). Four theories of the press: The authoritarian, libertarian, social responsibility, and Soviet Communist concepts of what the press should be and do. Chicago: University of Illinois Press.

Slay, H., et al. (Eds.). (2011). Professional identity construction: Using narrative to understand the negotiation of professional and stigmatized cultural identities. Human Relations, 64(1), 85-107.

Wilensky, H. (1964). The professionalization of everyone? American Journal of Sociology, 70(2), 137-158.

Xie, M. (2018). The top ten practical cases of China's newspaper transformation in 2017. Retrieved from $\mathrm{http}: / /$ www.sohu.com/a/218054549_654813

Yuan, S. J. (2014). Joy and worry in the transformation of Chinese newspaper industry. Retrieved from http://news.xinhuanet.com/newmedia/2014-10/28/c_127150731.htm

Zelizer, B. (1993). Journalists as Interpretive Communities. Critical Studies in Mass Communication, 10(2), $219-237$. 